\title{
HUBUNGAN GAYA KEPEMIMPINAN KEPALA PERAWAT DENGAN PENINGKATAN KINERJA PERAWAT PELAKSANA DI RS PERMATA PAMULANG
}

\author{
Lela Kania \\ Sekolah Tinggi Ilmu Kesehatan Kharisma Persada \\ Tangerang Selatan, 15417 \\ E-mail: lila.kania@gmail.com
}

\begin{abstract}
ABSTRAK
Latar Belakang: Kinerja perawat berperan penting dalam meningkatkan mutu layanan rumah sakit. Faktor yang dapat mempengaruhi kinerja adalah gaya kepemimpinan kepala perawat. Tujuan penelitian : untuk mengidentifikasi hubungan gaya kepemimpinan kepala perawat dengan kinerja perawat pelaksana di RS Permata Pamulang. Metode: Disain penelitian menggunakan deskriptif korelasi dengan pendekatan potong lintang (cross sectional) terhadap 80 perawat. Instrumen yang digunakan adalah kuesioner yang disusun berdasarkan elemen-elemen gaya kepemimpinan sedangkan untuk kinerja perawat menggunakan data sekunder dari RS Permata Pamulang. Hasil uji validitas dan reliabilitas didapatkan seluruh pernyataan dalam kuesioner adalah valid. Analisis data menggunakan analisis univariat, bivariat dan multivariat. Hasil: Hasil penelitian menunjukkan variabel yang berhubungan bermakna dengan kinerja adalah variabel kepemimpinan orientasi tugas $\mathrm{p}$ value 0.002 ( $\mathrm{p}$ value $<0.05$ ). Hasil analisis didapat odds ratio $(\mathrm{OR})$ dari variabel-variabel orientasi tugas adalah 0.145 (95\% CI:0.43-0.490), beratiorientasi tugas tinggi 0.145 kali berpeluang untuk memiliki kinerja baik dibanding yang berorientasi tugas rendah. Sedangkan hasil analisis odds ratio (OR) dari variabel-variabel orientasi karyawan adalah 0.443 (95\%CI:0.142-1.389), berarti orientasi karyawan tinggi 0.443 kali untuk berkinerja baik dibanding yang berorientasi karyawan rendah. Kesimpulan: Gaya kepemimpinan berorientasi karyawan mempunyai hubungan dengan kinerja perawat pelaksana tetapi yang paling menunjukkan hubungan bermakna adalah gaya kepemimpinan berorientasi tugas.
\end{abstract}

Kata kunci : : Gaya Kepemimpinan, Kinerja Perawat, Mutu Layanan Rumah Sakit

\begin{abstract}
Background: Nurse performance plays an important role in improving the quality of hospital services. Factors that can affect performance are the leadership style of the head nurse. The purpose of the study: to identify the relationship between the leadership style of the head nurse and the performance of the implementing nurses at Permata Pamulang Hospital. Method: The study design used descriptive correlation with a cross sectional approach to 80 nurses. The instrument used was a questionnaire prepared based on elements of leadership style while for nurse performance using secondary data from Permata Pamulang Hospital. The results of the validity and reliability tests obtained all statements in the questionnaire are valid. Data analysis used univariate, bivariate and multivariate analyzes. Results: The results showed that the variable which was significantly related to performance was the task orientation leadership variable $p$ value 0.002 ( $p$ value <0.05). The analysis results obtained odds ratio $(O R)$ of the task orientation variables is 0.145 (95\% CI: 0.43-0.490), high task oriented 0.145 times have the opportunity to have good performance compared to low task oriented. While the odds ratio (OR) results of the employee orientation variables are 0.443 (95\% CI: 0.142-1.389), meaning that the employee orientation is high 0.443 times for good performance compared to those with low employee orientation. Conclusion: The employee-oriented leadership style has a relationship with the performance of the implementing nurse but what shows the most meaningful relationship is the task-oriented leadership style.

Keywords: Leadership Style, Nurse Performance, Hospital Service Quality
\end{abstract}




\section{PENDAHULUAN}

Rumah sakit merupakan organisasi instistusi pelayanan kesehatan yang memiliki visi, misi serta tujuan yang hendak dicapai memiliki kekuatan yang besar dalam mempengaruhi kemampuannya mengelola sumber daya manusia sehingga tercapai kualitas pelayanan yang optimal. Kualitas pelayanan kesehatan yang dihasilkan rumah sakit sangat dipengaruhi oleh kinerja pemberi pelayanan kesehatan, salah satunya adalah profesi perawat. Sebagian besar pelayanan kesehatan yang dilakukan diberikan oleh perawat yang merupakan tenaga kesehatan dengan proporsi terbesar 40 - 60\% (Gillies, 1996). Oleh karena itu perawat dituntut untuk prima dalam memberikan pelayanan kepada klien dan meningkatkan kemampuan asuhan keperawatan serta kinerjanya. Dengan demikian kontribusi perawat sebagai salah satu pemberi pelayanan kesehatan ikut menentukan tercapainya tujuan rumah sakit. Rumah sakit adalah organisasi padat tenaga kerja dengan variasi status dan keahlian yang sangat luas. Salah satu karakteristik yag membuat rumah sakit sangat berbeda dengan orgaisasi lain yang juga padat karya adalah proporsi profesional SDM rumah sakit relatif tinggi sehingga membutuhkan keahlian tersendiri dalam mengelolanya. Dengan padatnya tenaga kerja dan variasi fungsi dan tugas yang sangat luas membawa konsekuensi kompleksnya masalah SDM rumah sakit. Kesulitan besar lainnya adalah pemberian imbalan dan insentif yang berdasarkan kinerja akan sangat sulit dilakukan karena terbatasnya dana dan penilaian kinerja yang efektif. Pada kondisi demikian sangat sulit meningkatkan produktifitas dan kualitas kerja rumah sakit. Tingginya beban kerja personal rumah sakit berdampak terhadap penurunan terhadap prestasi kerja. Hal ini dapat terjadi terutama bila naiknya beban kerja tanpa diikuti dengan peningkatan imbalan. Bila ini dibiarkan terus terjadi dapat berdampak kepada penurunan motivasi kerja yang selanjutnya berdampak terhadap produktivitas kerja, penurunan motivasi kerja penurunan tingkat kepuasan kerja. Gejala penurunan motivasi, prestasi kerja dan kepuasan kerja merupakan tanda bagi manajemen rumah sakit untuk mengkaji dan merencanakan SDM.

Perubahan zaman yang begitu cepat membuat peran perencanaan strategis menjadi begitu penting. Bahkan ini akan menjadi lebih sulit diformulasikan dalam pengelolaan suatu rumah sakit yang padat tenaga kerja. Dengan banyak masalah yang harus dipikirkan dengan SDM yang terbatas para manajer perlu memfokuskan dan menekankan pada masalah-masalah 
rumah sakit yang benar-benar penting termasuk masalah SDM. Perubahan yang besar yang terjadi pada dunia bisnis sangat sulit untuk diprediksi. Kesigapan pimpinan untuk merespon perubahan yang perlu dilakukan merupakan kompetensi yang sangat dibutuhkan. Pendekatan kreatif untuk dapat mengembangkan kebijakan yang dapat menghemat pembiayaan sekaligus mempertahankan kuantitas dan kualitas produksi menjadi kebutuhan mutlak organisasi. Pada tim kerja, pemimpin lebih berperan sebagai fasilitator yang mengembangkan, mengkordinasikan dan memotivasi anggota tim untuk menyelesaikan pekerjaan mereka. Pemimpin tim yang sukses dapat menciptakan atmosfer kerja yang mendorong anggota tim untuk melakukan analisis masalah, mencari solusi, dan berpartisipasi dalam pengambilan keputusan. Tim perencana SDM rumah sakit perlu melakukan riset terhadap situasi tenaga yang ada dirumah sakit saat ini. Pengetahuan tentang budaya kerja, motivasi kerja, beban kerja, kepuasan kerja, kinerja dan fasilitas kerja merupakan informasi penting untuk merencanakan SDM secara baik.

Dreher dan Dougherty (2001) dalam bukunya yang berjudul Human Resource Strategy : A Behavioral Perspective for The General Manajer menjelaskan bahwa untuk mengaplikasikan program human resource kita sebaiknya memahami beberapa teori dasar tentang kemampuan, motivasi dan peluang. Pemahaman teori tersebut setidaknya membuat para pemimpin belajar tentang perbedaan antara kemampuan perawat, motivasi dan peluang, dan mengapa perbedaanperbedaan tersebut sangat penting dalam mengembangkan kinerja perawat.Bila pemimpin menguasai teori tersebut diharapkan menjadi paham dengan beberapa sikap, kompetensi dan ciri personal lainnya yang mungkin berperan besar dalam membangun kinerja perawat secara efektif.

Kinerja perawat pelaksana merupakan serangkaian kegiatan perawat dalam memberikan asuhan keperawatan. Kinerja yang baik merupakan cerminan mutu pelayanan keperawatan yang diberikan. Terbentuknya kinerja perawat yang baik dapat dipengaruhi oleh sistem nilai bersama yang ada pada budaya rumah sakit dan gaya kepemimpinan para manajer rumah sakit. Gaya kepemimpinan yang baik akan mendorong timbulnya loyalitas pada organisasi,peningkatan motivasi serta produktivitas yang dapat berpengaruh terhadap laju roda organisasi, yang akhirnya akan menghasilkan kinerja perawat optimal sebagai penentu dalam mewujudkan kualitas pelayanan keperawatan dan citra pelayanan kesehatan 
di rumah sakit (Depkes RI, 1994; Rijadi, 2007).

Kepala perawat sebagai pemimpin terdepan memiliki kesempatan yang lebih besar dalam mempengaruhi orang lain untuk mencapai tujuan organisasi. Gilles (1996), menjelaskan bahwa seorang perawat pimpinan merupakan penggerak bawahannya agar mau bekerja sesuai dengan filosofi, visi dan misi yang ada pada organisasinya sehingga kinerja organisasi dapat meningkat. Oleh karena itu diperlukan kemampuan kepemimpinan yang tinggi dari kepala ruangan sehingga dapat mempengaruhi perawat pelaksana yang berada dibawah tanggung jawabnya.

Hasil penelitian Rahmayati (2002), menyatakan ada hubungan bermakna antara kepemimpinan dengan kinerja. Selanjutnya Baidoeri (2003), menemukan ada hubungan antara kepemimpinan kepala ruang dengan kinerja. Hal ini diperkuat hasil penelitian Hadi (2003), menemukan ada hubungan antara gaya kepemimpinan kepala ruangan dalam menerapkan fungsi manajemen keperawatan terhadap kinerja perawat pelaksana. Beberapa temuan tersebut memperlihatkan bahwa gaya kepemimpinan kepala ruang memiliki hubungan terhadap kinerja perawat pelaksana. Untuk itu rumah sakit perlu mengembangkan strategi dalam meningkatkan kepemimpinan kepala ruang khususnya gaya kepemimpinan, dalam upaya peningkatan efektifitas dan mencapai tujuan organisasi. Hal ini tentunya tidak terlepas dari perananmanajemen sumber daya manusia yang harus berperan secara professional dan berfungsi efektif.

Rumah Sakit X yang terletak di Kecamatan Pamulang mempunyai Visi "Menjadi Rumah Sakit yang memenuhi kebutuhan keluarga dalam masyarakat secara holistik, dengan layanan tepat dan profesional". Rekomendasi Tempat Tidur pada fase awal adalah 50 TT dengan kapasitas penuh mencapai 120 TT.Hasil penilaian kinerja rumah sakit pada tahun pertama dari BOR 16, 7\% pada akhir tahun 2012 meningkat menjadi 26,1\%. Sumber daya tenaga perawat 80 orang perawat dengan kualifikasi pendidikan S1 keperawatan 8 orang, D3 keperawatan 69 orang, dan SPK 1 orang dan SPRG 2 orang. Melalui observasi tugas dan fungsi dari masing-masing jabatan di unit keperawatan RS Permata Pamulang sudah disusun secara terperinci berdasarkan jabatannya, uraian tugas ini kemudian menjadi acuan bagi tenaga keperawatan sesuai dengan jabatannya masing-masing. Uraian tugas unit keperawatan ini terdiri dari : Kepala Bidang Keperawatan, Koordinator Ruang Kamar Operasi, Koordinator Ruangan Koordinator HCU \& ICU, Koordinator Perinatologi, 
Koordinator Ruangan Rawat Inap, pekerjaan sesuai dengan tugasnya masingKoordinator Ruangan Rawat Jalan, masing. Disamping itu budaya organisasi Koordinator IGD serta Perawat Pelaksana. yang kuat yang diterapkan dalam Untuk kesejahteraan perawat pelayanan juga ikut berperan dalam diberikan gaji, insentif, tunjangan menentukan kinerja perawat pelaksana kesehatan sedangkan untuk yang dirasa masih belum sesuai dengan pengembangan perawat diberikan harapan Untuk itu peneliti tertarik pelatihan internal dan eksternal, namun melakukan penelitian dengan judul belum ada program untuk pemberian penghargaan kepada perawat yang berprestasi. Saat ini supervisi dan penilaian kinerja dilakukan namun belum terstruktur, sehingga hasilnya belum optimal. Fenomena di atas menunjukkan bahwa kinerja perawat pelaksana masih perlu ditingkatkan secara maksimal dalam memberikan pelayanan keperawatan, karena kinerja merupakan bagian penting yang mempengaruhi mutu pelayanan keperawatan. Sementara itu kemampuan kepala ruangan memiliki keterbatasan menerapkan gaya kepemimpinan dalam memimpin stafnya untuk dapat melakukan

\section{METODE}

Penelitian ini mempergunakan desain deskriptif korelatif dengan pendekatan potong lintang Cross sectional, untuk melihat hubungan antara gaya kepemimpinan koordinator perawat dengan kinerja perawat pelaksana di RS X. Penelitian deskriptif korelatif bertujuan menjelaskan hubungan antara variabel (Nursalam, 2002). Pendekatan potong

lintang (Cross sectional) yaitu pengukuran antara variabel dilakukan satu kali pada suatu waktu (Nursalam, 2002; Arikunto, 2006). Pada penelitian ini, variabel independen adalah gaya kepemimpinan Koordinator Perawat, dan variabel dependen adalah kinerja perawat pelaksana. Sedangkan variabel confounding adalah karakteristik perawat 
yang meliputi umur, jenis kelamin, pendidikan, dan lama kerja. Populasi dalam penelitian ini adalah seluruh perawat pelaksana yang bekerja di RS Permata Pamulang berdasarkan data Bulan September berjumlah 80 orang. Adapun kriteria inklusi sampel dalam penelitian ini adalah; a) Perawat pelaksana yang bekerja di RS Permata Pamulang; b) Perawat pelaksana yang tidak sedang: sakit, cuti hamil atau melahirkan, melanjutkan pendidikan,atau mengikuti pelatihan; c) Bersedia menjadi responden.

Instrumen penelitian merupakan sesuatu yang terpenting dan strategis kedudukannya di dalam keseluruhan kegiatan penelitian (Arikunto, 2006). Instrumen yang digunakan dalam penelitian ini berupa kuesioner yang terdiri dari 3 bagian kuesioner, yaitu: 1) Kuesioner A yang berisi tentang karakteristik responden berdasarkan teori Robbins (2006), yang meliputi 4 pertanyaan no $1-4$, terdiri dari umur, jenis kelamin, tingkat pendidikan, dan lama kerja. Data ini diambil langsung dari responden, dimana responden memberi jawaban dengan mengisi/ check list pada kuesioner. 2) Kuesioner B yang berisi tentang gaya kepemimpinan berdasarkan (Rivai, 2007; Bram, 2008), yang dikembangkan dan disesuaikan untuk keperluan penelitian terdiri dari 20 pernyataan, 16 pernyataan positif (favorable) serta 4 pernyataan negatif (unfavorabel). Merupakan data primer yang diambil langsung dari responden melalui kuesioner, untuk menggali persepsi perawat pelaksana tentang gaya kepemimpinan kepala ruang melalui jawaban yang tersedia, dengan menggunakan skala Likert. 3) Kuesioner C merupakan kuesioner yang menggali variabel kinerja perawat pelaksana yang dikembangkan dan disesuaikan untuk keperluan penelitian, berdasarkan dari data sekunder yaitu data penilaian kinerja yang dilaksanakan di RS X.

Alat pengumpulan data kuantitatif menggunakan wawancara dengan lembaran kuesioner. Pertanyaan yang diajukan didasarkan pada indikator perilaku yang muncul dari hasil kuesioner. Untuk mengurangi terjadinya kesalahan maka peneliti melakukan uji coba kuesioner melalui Uji Validitas dengan cara menghitung nilai korelasi masingmasing item kuesioner dengan skor total dengan menggunakan korelasi pearson product moment dari Pearson dan membandingkannya dengan nilai $\mathrm{r}$ hitung dengan nilai $r$ tabel $(\mathrm{df}=\mathrm{n}-2)$ pada tingkat kemaknaan 95\%. Bila $\mathrm{r}$ hitung lebih besar dari $\mathrm{r}$ tabel dapat dikatakan bermakna, maka kuesioner dianggap valid. Dan yang kedua adalah dengan melalukan Uji Reliabilitas yang dilakukan setelah uji validitas dengan teknik Alpha Cronbach's. 
Bila nilai $r$ hitung dari Cronbach's Alpha lebih besar dari $r$ tabel, maka soal dianggap reliabel (Hastono, 2007).
Menurut Kuncoro, (2005) dan Danim, (2003), jika $r$ alpha lebih besar dari 0,9 maka instrumen tersebut sangat reliabel.

\section{HASIL}

\section{Deskripsi Data univariat}

Berdasarkan karakteristik informan pada Tabel 1, dari 80 informan jenis kelamin, laki-laki sebanyak 20\% dan perempuan sebanyak $80 \%$. Proporsi usia terbesar informasn adalah rentang usia 2029 tahun sebanyak $72.5 \%$ dan sebanyak $27,5 \%$ untuk usia $>30$ tahun. Sebagian besar informasi berpendidikan Diploma dan selebihnya S1 dengan komposisi Diploma sebanyak 90\% dan Sarjana sebanyak $10 \%$. Sebagian besar informan mempunya masa kerja 1 tahun sebanyak $51,2 \%$ selebihnya dengan masa kerja 2 tahun sebanyak $40 \%$, masa kerja 3 tahun sebanyak $5 \%$ dan masa kerja 4 tahun sebanyak 3,8\%. Berdasarkan karakteristik instalasi sebagian besar responden adalah karyawan bagian rawat inap sebanyak $48.8 \%$, rawat jalan $17.5 \%$, IGD $7.5 \%$, kamar operasi $11.2 \%$ dan Perina sebanyak $15.0 \%$.

Tabel 1. Karakteristik informan

\begin{tabular}{|c|c|c|c|}
\hline Karakteristik & Kategori & Jumlah & Persentase \\
\hline \multirow[t]{2}{*}{ Jenis Kelamin } & Laki-laki & 16 & $20 \%$ \\
\hline & Perempuan & 64 & $80 \%$ \\
\hline \multirow[t]{2}{*}{ Usia } & 20 - 29 Tahun & 58 & $72,5 \%$ \\
\hline & $>30$ Tahun & 22 & $27,5 \%$ \\
\hline \multirow[t]{2}{*}{ Pendidikan } & Diploma & 72 & $90 \%$ \\
\hline & Sarjana & 8 & $10 \%$ \\
\hline \multirow[t]{4}{*}{ Masa Kerja } & 1 Tahun & 41 & $51,2 \%$ \\
\hline & 2 Tahun & 32 & $40 \%$ \\
\hline & 3 Tahun & 4 & $5 \%$ \\
\hline & 4 Tahun & 3 & $3,8 \%$ \\
\hline \multirow[t]{5}{*}{ Instalasi } & Rawat Inap & 39 & $48,8 \%$ \\
\hline & Rawat Jalan & 14 & $17,5 \%$ \\
\hline & IGD & 6 & $7,5 \%$ \\
\hline & Kamar Operasi & 9 & $11,2 \%$ \\
\hline & Perina & 12 & $15 \%$ \\
\hline
\end{tabular}




\begin{tabular}{|c|c|c|c|c|}
\hline \multicolumn{2}{|c|}{ Karakteristik } & \multirow{2}{*}{$\begin{array}{l}\text { Kategori } \\
\text { Tinggi }\end{array}$} & \multirow{2}{*}{$\begin{array}{c}\text { Jumlah } \\
43\end{array}$} & \multirow{2}{*}{$\begin{array}{c}\text { Persentase } \\
53,8 \%\end{array}$} \\
\hline Distribusi & Frekuensi & & & \\
\hline Responden & Berdasarkan & Rendah & 37 & $46,2 \%$ \\
\hline Gaya & Kepemimpinan & & & \\
\hline \multicolumn{5}{|c|}{ Orientasi Tugas } \\
\hline Distribusi & Frekuensi & Tinggi & 47 & $58,8 \%$ \\
\hline Responden & Berdasarkan & Rendah & 33 & $41,2 \%$ \\
\hline Gaya & Kepemimpinan & & & \\
\hline \multicolumn{5}{|c|}{ Orientasi Karyawan } \\
\hline Distribusi & Frekuensi & Tinggi & 55 & $68,8 \%$ \\
\hline Responden & Berdasarkan & Rendah & 25 & $31,2 \%$ \\
\hline Kinerja & & & & \\
\hline
\end{tabular}

\section{Analisis Bivariat}

Analisis bivariat menggunakan uji chi-square untuk menguji hipotesis hubungan antara variabel dependen terhadap kinerja. Uji chi-square menggunakan batas kemaknaan $\alpha 0,05$. Bila P-value $<0,05$ maka ada hubungan yang bermakna antara variabel dependen dan variabel independen yang diteliti, sebaliknya jika P-value > 0,05 maka tidak ada hubungan yang bermakna di antara kedua variabel.

Dari hasil analisa statistik berdasarkan jenis kelamin, perawat pelaksana laki-laki sebanyak 13 orang $(23.6 \%)$ berkinerja baik dan perawat perempuang sebanyak 42 orang $(76.4 \%)$ berkinerja baik. Hasil analisis tersebut menunjukkan bahwa tidak ada hubungan yang bermakna antara jenis kelamin dengan kinerja.
Berdasarkan jenjang pendidikan sebanyak 49 orang $(89.1 \%)$ lulusan D3 keperawatan memiliki kinerja baik dan 6 orang (10.9\%) lulusan S1 Keperawatan berkinerja baik. Hasil analisis menunjukkan bahwa tidak ada hubungan yang bermakna antara pendidikan responden dengan kinerja ( $\mathrm{P}$-value $>0,05)$.

Dari hasil analisa statistik diketahui sebanyak 31 orang (56.4\%) dengan masa kerja 1 tahun memiliki kinerja baik dan sebanyak 17 orang (30.9\%) dengan masa kerja 2 tahun memiliki kinerja baik. Dari hasil analisis menunjukkan bahwa ada hubungan yang bermakna antara masa kerja responden dengan kinerja $(\mathrm{P}$-value < $0,05)$.

Dari hasil analisa statistik diketahui sebanyak 41 orang $(74.5 \%)$ perawat pelaksana yang berumur 20-29 tahun memiliki kinerja baik dan sebanyak 14 
orang $(25.5 \%)$ perawat pelaksana yang berumur $\geq 30$ tahun memiliki kinerja baik. Hasil analisis menunjukkan bahwa tidak ada hubungan yang bermakna antara usia responden dengan kinerja $(\mathrm{P}-\mathrm{value}>0,05)$.

Tabel 2. Analisis Bivariat

\begin{tabular}{|c|c|c|c|c|c|c|}
\hline \multirow{3}{*}{ Kategori } & \multicolumn{4}{|c|}{ Kinerja } & \multirow{3}{*}{ Total } & \multirow{3}{*}{ P-value } \\
\hline & \multicolumn{2}{|c|}{ Baik } & \multicolumn{2}{|c|}{ Kurang } & & \\
\hline & $\mathbf{n}$ & $\%$ & $\mathbf{n}$ & $\%$ & & \\
\hline Laki-laki & 13 & 23.6 & 3 & 20 & 16 & \multirow{2}{*}{0,184} \\
\hline Perempuan & 42 & 76.4 & 22 & 80 & 64 & \\
\hline Diploma & 49 & 89.1 & 23 & 92.0 & 72 & \multirow{2}{*}{0,517} \\
\hline Sarjana & 6 & 10.9 & 2 & 8.0 & 8 & \\
\hline 1 Tahun & 31 & 56,4 & 10 & 40,0 & 41 & \multirow{4}{*}{0,002} \\
\hline 2 Tahun & 17 & 30,9 & 15 & 60,0 & 32 & \\
\hline 3 Tahun & 4 & 7,3 & 0 & 0 & 4 & \\
\hline 4 Tahun & 3 & 5,5 & 0 & 0 & 3 & \\
\hline 20-29 Tahun & 41 & 74,5 & 17 & 68,0 & 52 & \multirow{2}{*}{0,422} \\
\hline 30-39 Tahun & 14 & 25,5 & 8 & 32,0 & 20 & \\
\hline
\end{tabular}

Dari hasil analisa statistik Hubungan pelaksana yang mempersepsikan gaya Gaya Kepemimpinan Orientasi Tugas kepemimpinan orientasi tugas rendah dengan Kinerja diketahui sebanyak 22 memiliki kinerja baik. Hasil analisis orang (40\%) perawat pelaksana yang menunjukkan bahwa terdapat hubungan mempersepsikan gaya kepemimpinan yang bermakna antara gaya kepemimpinan orientasi tugas tinggi memiliki kinerja baik berorientasi tugas dengan kinerja (P-value dan sebanyak 33 orang $(60 \%)$ perawat $<0,05)$.

Tabel 3. Hubungan Gaya Kepeimpinan Orientasi Tugas

\begin{tabular}{l|c|c|c|c|c|c}
\hline \multirow{2}{*}{$\begin{array}{c}\text { Gaya } \\
\text { Kepemimpinan } \\
\text { Orientasi } \\
\text { Tugas }\end{array}$} & \multicolumn{4}{|c|}{ Kinerja } & \multirow{2}{*}{ Total } & \multirow{2}{*}{ P-value } \\
\cline { 2 - 5 } & $\mathbf{n}$ & $\%$ & $\mathbf{n}$ & $\%$ & & \\
\hline Tinggi & 22 & 60 & 21 & 84,0 & 43 & \multirow{2}{*}{ Kurang } \\
Rendah & 33 & 40 & 4 & 16,0 & 37 & 0,000 \\
\hline
\end{tabular}


Sedangkan Dari hasil analisa statistik diketahui sebanyak 28 orang $(50.9 \%)$ perawat pelaksana yang mempersepsikan gaya kepemimpinan yang berorientasi karyawan tinggi memiliki kinerja baik dan sebanyak 27 orang $(49.1 \%)$ perawat pelaksana yang mempersepsikan gaya kepemimpinan orientasi karyawan rendah memiliki kinerja baik. Hasil analisis menunjukkan bahwa terdapat hubungan yang bermakna antara gaya kepemimpinan orientasi karyawan dengan kinerja $(\mathrm{P}$ value $<0,05)$.

Tabel 4. Hubungan Gaya Kepemimpinan Orientasi Karyawan

\begin{tabular}{l|c|c|c|c|c|c}
\hline \multirow{2}{*}{$\begin{array}{l}\text { Gaya Kepemimpinan } \\
\text { Orientasi Karyawan }\end{array}$} & \multicolumn{4}{|c|}{ Kinerja } & \multirow{3}{*}{ Total } & \multirow{2}{*}{ P-value } \\
\cline { 2 - 6 } & \multicolumn{2}{|c|}{ Baik } & \multicolumn{2}{c|}{ Kurang } & & \\
\cline { 2 - 6 } & $\mathbf{n}$ & $\%$ & $\mathbf{n}$ & $\boldsymbol{\%}$ & & \\
\hline Tinggi & 28 & 50,9 & 19 & 76,0 & 47 & \multirow{2}{*}{0,029} \\
Rendah & 27 & 49,1 & 6 & 24,0 & 33 & \\
\hline
\end{tabular}

\section{Analisis Bivariat}

Dari hasil analisis bivariat variabel orientasi tugas adalah 0.145 menunjukan bahwa variable yang (95\%CI:0.43-0.490), sehingga orientasi berhubungan dengan kinerja perawat tugas tinggi 0.145 kali berpeluang untuk adalah masa kerja, gaya kepemimpinan memiliki kinerja baik dibanding yang orientasi tugas dan gaya kepemimpinan berorientasi tugas rendah. Sedangkan hasil orientasi karyawan. Hasil penelitian analisis odds ratio (OR) dari variabelmenunjukkan variabel yang berhubungan bermakna dengan kinerja adalah variabel kepemimpinan orientasi tugas $\mathrm{p}$ value 0.002 ( $\mathrm{p}$ value <0.05). Hasil analisis didapat odds ratio (OR) dari variabelvariabel orientasi karyawan adalah 0.443 (95\%CI:0.142-1.389), sehingg orientasi karyawan tinggi 0.443 kali untuk berkinerja baik dibanding yang berorientasi karyawan rendah. 
PEMBAHASAN

\section{Hubungan karakteristik perawat dengan kinerja perawat di RS Permata Pamulang}

\section{Jenis Kelamin}

Berdasarkan hasil analisis didapatkan bahwa proporsi perempuan yang menunjukan kinerja lebih besar daripada yang berkinerja kurang. Secara statistik tidak ada hubungan yang bermakna antara jenis kelamin dengan kinerja. Hasil penelitian ini sesuai dengan penelitian Sihombing (2005); Baidoeri (2003); Lumbantoruan (2005); Lusiani (2006); Bram (2008), bahwa jenis kelamin perawat pelaksana tidak berhubungan secara bermakna dengan kinerja. Menurut Robbins (2006) tidak ada perbedaan yang bermakna antara jenis kelamin dengan produktivitas dalam kinerja antara jenis kelamin laki-laki dan wanita.

\section{Pendidikan}

Hasil penelitian menunjukan bahwa tingkat pendidikan perawat pelaksana yang berpendidikan D3 Keperawatan mempunyai proporsi yang lebih besar dibanding S1 Keperawatan. Sehingga dihasilkan analisis bahwa tidak ada hubungan yang bermakna antara pendidikan lebih tinggi akan berhubungan dengan kinerja perawat pelaksana. Hasil penelitian ini selaras dengan penelitian Mila Triana Sari (2009); Lusiani (2006); Rusmiati (2007); Sihombing (2005); Baidoeri (2003), yang menyatakan bahwa tingkat pendidikan tidak berhubungan secara signifikan dengan kinerja perawat. Meskipun hasil penelitian ini menunjukkan bahwa tingkat pendidikan tidak memiliki hubungan dengan kinerja, untuk dapat mencapai visi rumah sakit menjadi rumah sakit pilihan dan pusat rujukan melalui pelayanan prima, sebaiknya pendidikan perawat di rumah sakit perlu ditingkatkan.

\section{Lama Kerja}

Berdasarkan analisis penelitian menunjukan bahwa ada hubungan bermakna antara masa kerja dengan kinerja perawat. Hasil penelitian ini selaras dengan hasil penelitian (Lusiani, 2006; Panjaitan, 2002), mengungkapkan lama kerja mempunyai hubungan yang bermakna dengan kinerja. Pendapat Hersey \& Blanchard (1993), bahwa pengalaman kerja yang diperoleh seseorang sangat mempengaruhi kemampuannya dan diasumsikan bahwa semakin lama seseorang bekerja makan kemampuan dia untuk memahami tugas dan fungsinya akan semakin tinggi.

Hasil penelitian ini tidak selaras dengan hasil penelitian (Ilyas, 2002; 
Rusmiati, 2006; Baidoeri, 2003), yang menyatakan tidak ada hubungan lama kerja dengan kinerja. Robbins (2006), menjelaskan pengalaman kerja yang lama belum tentu menjamin kinerja yang baik, karena walaupun seorang perawat memiliki pengalaman kerja yang lama serta keterampilan yang cukup dalam melaksanakan tugasnya, jika tidak didukung oleh lingkungan dan fasilitas yang cukup, maka potensi yang dimiliki perawat tidak akan berdampak positif pada pekerjaannya bekerja, maka akan semakin baik kemampuannya.

\section{Umur}

Variabel umur pada penelitian ini tidak menunjukkan adanya hubungan yang bermakna dengan kinerja perawat di RS Permata Pamulang. Hasil penelitian ini mendukung hasil penelitian yang dilakukan Mila Triana Sari (2009), Lusiani (2006); Prawoto (2007); Rusmiati (2006) dan Baidoeri (2003), yang menyatakan bahwa umur tidak berhubungan secara signifikan dengan kinerja perawat pelaksana. Hal ini terjadi karena tidak adanya perbedaan antara senior dan yunior dalam melaksanakan tugas diruangan sehingga menyebabkan tidak begitu mempengaruhi kinerja perawat diruangan. Padahal menurut Hasibuan (2003), umur akan mempengaruhi kondisi fisik, mental, kemampuan kerja dan tanggung jawab seseorang. Karyawan yang umurnya lebih tua kondisi fisiknya kurang, tetapi bekerja ulet, mempunyai kedewasaan teknis dan psikologis serta bertanggung jawab besar.

Levinston (1994, dalam Susana, 2003, Mila Triana, 2009), yang menyatakan bahwa usia antara 22-30 tahun merupakan tahap usia memasuki usia dewasa, dimana umumnya pada masa ini seseorang memulai komitmen untuk masa depan dan merupakan fase pekerjaan yang ditandai dengan pencarian identitas dan pencapaian tujuan karir yang memuaskan.

\section{Hubungan Gaya Kepemimpinan} Koordinator/ Kepala Perawat berorientasi tugas dengan Kinerja

$$
\text { Gaya kepemimpinan ini }
$$
mengandalkan kekuatan paksaan, imbalan dan hukuman untuk mempengaruhi sifat dan prestasi pengikutnya (Rivai, 2007). Dalam penelitian ini gaya kepemimpinan kepala perawat berorientasi tugas adalah persepsi perawat pelaksana terhadap perilaku kepala perawat pada saat mengarahkan dan mempengaruhi bawahannya dengan indikator batas waktu penyelesaian tugas dan memberikan arahan dan petunjuk kepada bawahan yang terkait dengan tugas tersebut.

Hasil penelitian menunjukkan gaya kepemimpinan berorientasi tugas tinggi berdampak pada kinerja kurang, sedangkan gaya kepemimpinan 
berorientasi tugas rendah berdampak pada kinerja baik. Hasil ini menunjukkan bahwa ada hubungan yang bermakna antara gaya kepemimpinan orientasi tugas dengan kinerja perawat pelaksana. Hasil penelitian ini sesuai dengan penelitian Sulikah (2001), yang menemukan bahwa ada hubungan bermakna antara hubungan gaya kepemimpinan berorientasi tugas rendah dengan orientasi struktur tugas.

Berdasarkan hasil penelitian tersebut peneliti melihat bahwa gaya kepemimpinan kepala perawat yang berorientasi tugas tinggi telah memiliki target pekerjaan untuk dilakukan oleh stafnya yang berdampak pada kinerja baik. Kepala perawat saat ini telah mempunyai rencana kerja yang terorganisir dan telah mempunyai evaluasi hasil kerja yang telah dicapai oleh staf keperawatan.

\section{Hubungan Gaya Kepemimpinan} Koordinator/ Kepala Perawat berorientasi Karyawan dengan Kinerja

Pemimpin yang berpusat pada karyawan memiliki perhatian terhadap kemajuan pertumbuhan dan prestasi pribadi pengikutnya. Dalam penelitian ini gaya kepemimpinan berorientasi karyawan adalah persepsi perawat pelaksana terhadap perilaku kepala perawat pada saat mengarahkan dan mempengaruhi bawahannya dengan indicator mendukung dan mendorong bawahan serta keinginan berkonsultasi dan bermusyawarah.

Hasil penelitian mengungkapkan perawat pelaksana yang mempersepsikan gaya kepemimpinan kepala perawat yang berorientasi karyawan tinggi memberikan dampak kinerja baik yang lebih baik deibandingkan dengan gaya kepemimpinan berorientasi karyawan rendah. Hasil ini juga menunjukan bahwa ada hubungan bermakna antara gaya kepemimpinan berorientasi karyawan dengan kinerka perawat pelaksana.

Hal ini selaras dengan hasil penelitian Mila Triana Sari (2009), Bram (2008), yang menyatakan ada hubungan yang bermakna antara gaya kepemimpinan kepala ruang berorientasi karyawan dengan kinerja. Baidoeri (2003), yang menyatakan kepemimpinan supportif kepala ruangan mempunyai hubungan yang signifikan dengan kinerja perawat.

\section{Faktor yang paling berhubungan dengan kinerja perawat pelaksana}

Hasil analisis multivariate yang dilakukan pada variabel yang mempunyai hubungan bermakna dengan kinerja perawat pelaksana menunjukkan bahwa variable yang paling berhubungan adalah gaya kepemimpinan berdasarkan orientasi tugas dengan $\mathrm{p}$ value $=0.002(\mathrm{p}$ value $<$ 0.05).Hasil analisis odds ratio (OR) dari 
variabel-variabel orientasi karyawan

adalah 0.145 (95\%CI:0.43-0.490).

\section{KESIMPULAN}

Berdasarkan hasil dan pembahasan dalam penelitian ini, maka peneliti dapat menarik kesimpulan bahwa karakteristik perawat pelaksana di RS Permata Pamulang sebagian besar berjenis kelamin perempuan dan rata-rata umur 20-30, dengan tingkat pendidikan sebagian besar D3 Keperawatan dan rata-rata lama kerja adalah 1 tahun dengan gaya kepemimpinan kepala perawat yang dipersepsikan oleh perawat pelaksana adalah berimbang antara gaya kepemimpinan berorientasi tugas dengan gaya kepemimpinan berorientasi karyawan. Perawat pelaksana

\section{SARAN}

Berdasarkan temuan penelitian disarankan untuk manajemen RS untuk membuat kebijakan yang berkaitan dengan jenjang karir perawat secara professional berdasarkan uji kompetensi dengan memperhatikan masa kerja, tingkat pendidikan dan keterampilan sebagai dasar pengatur sistem penghargaan dan pengakuan atas dasar kinerja perawat dalam pengembangan diri dan untuk lebih memotivasi perawat pelaksana sehingga tidak terjadi turn over yang tinggi di bagian keperawatan RS Permata Pamulang. Secara berkesinambungan melakukan kegiatan-kegiatan dalam upaya
RS Permata Pamulang sebagian besar memiliki kinerja baik dilihat dari hasil evaluasi atau penilaian yang dilakukan secara berkala. Karakteristik perawat pelaksana yang meliputi, umur, jenis kelamin, pendidikan, masa kerja tidak mempunyai hubungan bermakna dengan kinerja.

Gaya kepemimpinan berorientasi karyawan mempunyai hubungan dengan kinerja perawat pelaksana tetapi yang paling menunjukkan hubungan bermakna adalah gaya kepemimpinan berorientasi tugas.

peningkatan kualitas leadership bagi para pemimpin di setiap unit kerja agar dapat berperilaku sebagai pemimpin yang mampu menerapkan gaya kepemimpinan sesuai dengan kebutuhan kondisi di unit kerja masing-masing. Pentingnya menerapkan gaya kepemimpinan yang seimbang dan tepat dengan kombinasi penerapan gaya kepemimpinan orientasi karyawan dan penerapan gaya kepemimpinan orientasi tugas. Membangun motivasi, kebutuhan untuk berprestasi serta etos kerja perawat dengan menciptakan lingkungan kerja yang lebih kondusif dan menyenangkan, maupun 
membuat program penghargaan bagi mendorong inisiatif atau ide-ide dari perawat berprestasi secara reguler bulanan perawat pelaksana untuk meningkatkan atau tahunan untuk perawat teladan, kepercayaan diri perawat pelaksana. demikian juga adanya sistem punishment Mensosialisasikan visi, misi, pedoman bagi karyawan yang bermasalah atau tidak keperawatan, standar procedure sesuai dengan nilai-nilai yang ada pada keperawatan dan asuhan keperawatan organisasi rumah sakit. Memfasilitasi kegiatan pelatihan secara reguler atau mengirimkan kepala ruangan untuk mengikuti pelatihan diluar rumah sakit berkenaan dengan kepemimpinan dan pengelolaan bangsal keperawatan. Membangun sistem komunikasi antara jajaran direksi dan manajemen dengan perawat mulai dari level manajemen terbawah dan perawat pelaksana melalui pertemuan secara berkala dan terprogram.

Untuk kepala perawat perlu lebih mengembangkan gaya kepemimpinan yang berorientasi pada perawat, menjalin hubungan interaksi yang baik, membangun tim yang kuat dan saling percaya, mulai saat orientasi dan dilakukan secara berkala agar perawat pelaksana bias mengerti, memahami dan menjiwai serta diaplikasikan pada kegiatan perawat.

Sedangkan untuk perawat pelaksana itu sendiri diharapkan mampu menerapkan nilai-nilai yang ada di RS Permata Pamulang dalam akivitas sehari-hari, berkomitmen untuk meningkatkan mutu pelayanan dengan menjalankan tugas sesuai dengan standar yang sudah ada untuk menjaga keselamatan pasien dan melakukan asuhan keperawatan yang optimal kepada pasien, disiplin waktu dan terlibat secara aktif dalam kegiatankegiatan yang ada di rumah sakit. 


\section{DAFTAR PUSTAKA}

Gillies, D. A. (1996). Manajemen Keperawatan: Suatu Pendekatan Sistem. (Dika, Penerjemah). Philadelphia: W.B. Sauders Company.

Nursalam. (2011) Manajemen Keperawatan Edisi 3

Rivai, Veithzal, 2003. Kepemimpinan dan Perilaku Organisasi, Edisi Pertama, PT Raja Grafindo, Jakarta

Riyadi, S. Kusnanto, H. (2007). Motivasi Kerja dan Karakteritik Individu Perawat di RS Dr.H.Moh. Anwar Sumenep Madura. Diperoleh dari http//:www.ugm.ac.id.pdf.

Rumah Sakit Permata Pamulang (2011, 2012, 2013). Profil Rumah Sakit Permata Pamulang dan penilaian kinerja perawat RS Permata Pamulang. 